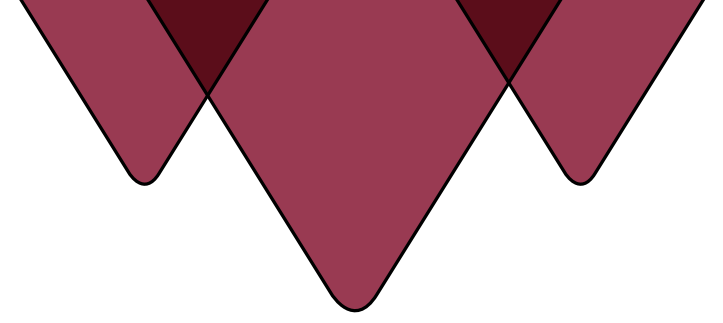

\title{
Leadership Development for Academic Librarians: Maintaining the Status Quo?
}

\author{
Samantha Hines \\ Peninsula College
}

\begin{abstract}
Leadership development programs within librarianship are immensely popular. The informal critiques that are leveled at these programs, however, claim that they serve only to reinforce the status quo and that they do not address the real issues affecting our profession, particularly those relating to racial and gender diversity. In order to critically determine the value of these programs, I examine them through the lens of critical race theory. Elements of critical race theory are illustrated through details solicited from the program coordinators and from available information on program websites and in professional literature. While these leadership programs frame themselves as creating transformational leaders, focusing on team-building, collaboration, and motivation, their curriculum and structure perpetuate the status quo in relation to librarianship's existing structural biases. There are steps that can be taken, however, to better develop diverse leaders with our professional values in mind.
\end{abstract}

Keywords: critical librarianship · diversity - leadership development · library development training

RÉSUMÉ

Les programmes de développement du leadership en bibliothéconomie sont extrêmement populaires. Les critiques informelles qui sont formulées à l'égard de ces programmes prétendent toutefois qu'ils ne servent qu'à renforcer le statu quo et qu'ils n'abordent pas les véritables problèmes qui touchent notre profession, en particulier ceux liés à la diversité des races et des genres. Afin de déterminer de façon critique la valeur de ces programmes, je les examine sous l'angle de la théorie critique de la race. Les éléments de la théorie critique de la race sont illustrés par des détails demandés aux coordonnateurs de programme et par des renseignements disponibles sur les sites Web des programmes et dans la documentation professionnelle. Bien que ces programmes de leadership soient conçus pour créer des leaders transformationnels, axés sur l'esprit d'équipe, la collaboration et la motivation, leur programme d'études et leur structure perpétuent le statu quo en ce qui a trait aux préjugés structurels actuels des bibliothécaires. Il y a toutefois des mesures qui peuvent être prises pour mieux former des leaders diversifiés tout en conservant nos valeurs professionnelles. 
Mots-clés : bibliothéconomie critique · diversité · développement du leadership · formation au leadership en bibliothéconomie

\section{Introduction}

Leadership development programs such as institutes, seminars, workshops, academies, and courses have been popular within librarianship for decades, following trends from the business world. Sponsored by associations, corporations, and educational institutions, these programs take a variety of forms: intensive and extensive, and online and face to face. As one who has been a longtime participant in them as an attendee, organizer, and instructor, I have collected anecdotal evidence indicating that these programs only reinforce the status quo in librarianship. They perpetuate the biased discourse and power structures inherent in society and do not address issues affecting our changing profession, particularly those of gender and racial diversity.

Looking through the lens of critical race theory, I examine how the curriculum and the structure of these leadership programs perpetuate the structural biases concerning race and gender in the status quo. This is not a comprehensive empirical study of leadership programs but rather a preliminary investigation, with the intent of opening a dialogue to reflect on current ways of training leaders in librarianship. We can make beneficial changes to leadership development training in librarianship, but only if we acknowledge the situations that perpetuate bias.

\section{Literature Review}

I have structured the literature review in three sections: Leadership, Diversity, and Critical Race Theory, in order to provide background on the relevant research in these areas with respect to my study of leadership programs in librarianship. Leadership and diversity are areas for which library professionals have expressed concern or desire for growth, and critical race theory offers a framework for the analysis to follow.

\section{Leadership}

A loud and growing concern among librarians is the greying of the profession and the need to recruit more librarians (Lenzini 2002), particularly for leadership positions (Nixon 2008). These concerns may have led to the development of leadership programs. In Skinner and Krabbenhoeft's (2014) review of library leadership training, they show that this training generally began to trend around the I980s. By the late I990s, several programs were up and running, most centred on a residential model involving a seminar several days in length. These offerings mostly focused on skill- 
building for managers at first and then on change management. Some were and still are focused on developing these skills for persons of colour. Around the turn of the 2Ist century, opportunities "expanded dramatically" (7) and began to diversify in model (Skinner and Krabbenhoeft 20I4).

Library leadership development, and leadership development generally, suffer from a conflation of the concepts of leadership and management. For the purposes of this paper, management is defined as the solving of technical problems, such as drafting policies, documenting employee performance, and dealing with difficult customers in the moment. Leadership is defined as higher-level concepts such as strategic planning, building community, and change management. Several approaches to leadership exist, but a major approach used for library leadershipdevelopment programs in my experience is "transformational leadership," defined by Burns (1978) as "[raising] followers' level of consciousness about the importance and value of desired outcomes and the methods of reaching those outcomes" (I4I). Transformational leadership consists of four components: idealized influence (behaving in a way that followers wish to emulate), inspirational motivation (providing shared meaning and challenge), intellectual stimulation (openness to critique), and individualized consideration (helping followers reach their potential) (McCleskey 20I4). Transformational leadership has been called "the single most studied and debated idea within the field of leadership" (Diaz-Saenz 20II, 299) and continues to be the main theory taught in corporate leadership development.

The majority of current library leadership development programs are multi-day residential programs or long-term fellowships and are delivered face to face. Most of them feature common components, goals, and modes of delivery. Guest speakers, discussions, mentors, and case studies feature most prominently. Curricula now tend to focus on change management and innovation (Jacobs 2015). These programs are seen as a good launching point into management positions in libraries, positions that have great impact on the formation of policies, initiatives, and strategies within individual libraries and the profession as a whole, not to mention hiring practices at specific institutions.

The library literature about these programs, like the programs themselves, focuses predominantly on the practical aspects (e.g., what programs are available, what they cost, and what skills are developed) rather than on a true evaluation of whether the curriculum is meeting the needs of the profession (Skinner and Krabbenhoeft 2OI4). I searched the LISTA database and Google Scholar several times between November 2016 and July 2017 for keywords such as leadership develop*, leadership train*, library leader*, and the names of specific offerings listed in the appendixes. I turned to the ACRL publication Creating Leaders: An Examination 
of Academic and Research Library Leadership Institutes (Herold 2015), hoping for a global examination of whether and how these programs meet the needs of the profession; there was no such information. That publication is in essence a guidebook of 18 programs offered in North America, written by past attendees and focused largely on their personal experiences. The concluding chapter pointed to the dearth of evidencebased data supporting the efficacy of these programs, stating that their value lies in building skills, increasing confidence, and entering into a professional network of named leaders in the profession (349-5I).

This dearth of evidence-based data is also mentioned in Skinner and Krabbenhoeft's (2OI4) report that reviews I5 years of library leadership training. Focusing exclusively on programs in the United States, the report mentions "notable lack of shared objectives or 'leadership competencies' driving these diverse offerings and evaluations of their successes/failures" (9). The report discusses the "personal influence of key players who have designed and facilitated multiple programs across more than a decade" (27) as an area of instability for evaluating the efficacy of these programs. The report concludes with several suggestions, among which is the need for such programs to operate in a more high-level, collaborative, and coordinated manner with one another and within the profession (29-30).

Further criticism of library leadership training in the literature is that there are limited training slots available for the profession globally and that most programs are offered only face to face and in economically developed countries. Thus leadership development programs are inaccessible to the majority of potential participants worldwide (Jacobs 2015), which affects access for those outside of the dominant white cultures of North America, Europe, and Australia.

\section{Diversity}

Librarianship as a profession needs to reflect the diversity of the communities in which it is situated, as the value statements of key professional organizations suggest that librarians desire to do so. For example, according to the American Library Association (2004), among the chief values of the profession of librarianship are:

- Access: information resources provided by the library should be readily, equally, and equitably accessible to all library users

- Democracy: free and equal access to information for all the people of the community the library serves

- Diversity: valuing diversity in services and resources, but also reflecting that diversity found within our communities

- Social responsibility: that librarianship can ameliorate or solve critical problems of society 
The International Federation of Library Associations (2018) embraces the value of freedom of access to information and ideas as essential for social, educational, cultural, democratic, and economic well-being. Many librarians respect the need for diversity of ideas, information, and opinions within the content and resources provided by libraries and are committed to serving their communities in an equitable manner, but they are generally less focused on reflecting diversity within the profession. For the purposes of this article, I will focus on two aspects of diversity: race and gender. While, in fairness, the ALA and many other professional groups have stated goals and active programs to recruit persons of colour to librarianship, the Diversity Counts study that ALA has conducted shows that only I2 percent of credentialed librarians in the United States in 2009 were racial and ethnic minorities (ALA 20I2). Results from the 2006 Canadian census estimate that a little under IO percent of librarians are visible minorities (Leong 2OI3). The CAPAL 2016 census indicates that, of the academic librarians responding, 2.2 percent consider themselves to be Indigenous, and an additional 9 percent consider themselves members of visible minority groups (36-37). This is far below the levels of persons of colour found in the general population of either nation: the visible minority population in the US is 39.3 percent according to 2017 census estimates (United States Census Bureau), and Canada's visible minority population is I9.I percent as of $201 \mathrm{I}$ (Statistics Canada).

While there are many criticisms of current library leadership programs (such as that they promote or express neoliberalism), this paper focuses on two sites of structural bias: gender and race. We will examine gender first. The \#libleadgender movement points out that while librarianship as a whole is 80 percent female, library leadership is only about 60 percent female (Olin and Millet 2015). The literature states that leadership programs address competencies and skills that "align with masculinized notions of management" and have "little consideration of the underlying conditions that shape leadership" (Neigel 2015, 527). Gender is a "peripheral topic of discussion" in these programs, which reinforces the status quo (53I).

Librarianship itself, as a feminized profession, reinforces structural sexism as it is performed in society, particularly in areas of higher education focusing on student support (Sloniowski 2016; Douglas and Gadsby 2017). "Real work," in particular the work of management and leadership, is seen as masculine, while the more relational work that librarians often engage in, such as collaboration, making connections, reducing barriers, and building consensus, is typically seen as female and thus made invisible (Fletcher 1995; Pfaff et al. 20I3). The only way to redefine relational work as effective and important to our profession is to address it directly within and also outside our discipline: 
We recognize movers, shakers, pushers, shovers, leaders, and change agents, but how do we acknowledge emotional labor and care work? We need to speak at more interdisciplinary tables, and we need to write precisely about our labor issues as well as about the politics of knowledge organization and how our work impacts the production culture of the academy.

(Sloniowski 2016, 663)

With regard to race, the issues for leadership are more varied due to lack of persons of colour within the library profession. The field in general has a "tendency to tiptoe around discussing race and racism, and instead limit the discourse by using words such as 'multiculturalism' and 'diversity'" as well as take on the perpetuation of white privilege inherent in the power structures surrounding and within librarianship (Honma 2005). Discourse on diversity needs to go beyond token inclusion of persons of colour to a true evaluation of why there are so few persons of colour in our profession. It needs to examine what role racism and power structures play, both in the services we offer and in the content we curate, and move toward a transformation of those structures. The concept of white normativity within librarianship that Honma (2005) describes is a powerful one: those who are white are seen as the "norm," while those who are not provide "diversity and multiculturalism" within the profession.

Looking at motivating what minority library workers we have in the profession to take on positions of leadership, Olivas discusses the need to demonstrate value both for the individual and for the particular organization the individual works in, to focus on the chance to give back to a larger community, and to look beyond extrinsic rewards such as pay (Olivas 2017). Supportive programs for recruitment and retention of minority library workers help but are often underfunded or lack variation (DavisKendrick 2009).

\section{Critical Race Theory}

One approach to take when looking at race in the profession is to examine the role that whiteness plays. As a profession that is profoundly white, we might examine from an ethnological perspective what that means for us within our libraries and for the communities that we serve. The concept of universalism can help illustrate: "In a white-dominated society, standards are applied and are described as neutral, universal and true for all people. But in fact the criteria are not universal. They come from a white perspective" (Espinal 200I, I4I). The existing power structures, roles, and rules in the library and in the profession have an inherent bias. They are not "the norm" that naturally applies to the human condition as a whole. There is no universal standard but rather a white point of view that is by nature exclusionary, particularly when it is regarded as universal. An additional benefit of this critical race theory approach is that it reduces the view that the racial diversity in the profession is the 
problem. Instead, it argues that the profession's problem is its whiteness. This is another, stronger view about the white normativity that Honma discusses (2005).

Applying critical race theory (CRT) to library leadership development will frame our understanding of these programs, in the aggregate, as pervasive of racial and gender inequality existing in our profession. CRT provides a conceptual framework for understanding inequalities arising from race and racism as well as approaches for challenging the power structures leading to these inequalities. CRT was originally developed in legal studies to address the realities of persons of colour (Delgado, Stefancic, and Liendo 2012, 3). Rather than rejecting acknowledgement of racial identity as racism, critical race theory "focused explicitly on the influence of racial identity on social justice and civil rights and the social mechanisms that caused de facto segregation and discrimination" (Gibson, Hughes-Hassell, and Threats 20I8, 5I). CRT in general has become more popular over the years in many fields, including LIS, and prompts discussions about power structures and ways of including or excluding.

Three tenets of CRT prove most relevant to the discussion of leadership development for library workers. The first is the idea of ordinariness, which sets forth that racism is difficult to address because it is deeply embedded in society (Delgado, Stefancic, and Liendo 20I2). Racism is seen as a "given," the way things are, and this can discourage action or make reasonable action feel ineffective. The ordinariness of racism can be seen in the universalism of whiteness present within librarianship as discussed by Espinal (200I) and the normativity of whiteness presented by Honma (2005).

Second, the concept of interest convergence or material determinism holds that racism advances the interests of those who benefit from it and that there is no incentive therefore to eradicate it (Delgado, Stefancic, and Liendo 20I2). Basically, the status quo is self-perpetuating, since it keeps those already in power on the top. Unless a reason to change arises that appeals to the self-interest of those in power, structures that keep them in power will persist.

This leads to the third tenet, structural determinism, which illustrates that structures are incapable of dealing effectively with racial bias due to how they are constructed or how they operate (Delgado, Stefancic, and Liendo 2012). For our purposes, the way academia is structured to educate library workers, the way libraries operate, and the way library leadership training works fundamentally reinforce societal biases. This is discussed heavily by Honma (2005) with regard to white normativity in LIS. If structures are set up to consider white librarians as normal and male managers as normal, what further barriers and difficulties will librarians of colour or women face because of them? 
Applying critical race theory to situations such as library leadership development allows us to better describe and understand the problems we face and explain their structural nature. CRT also offers tools for storytelling and narrative as we seek ways to address these problems by building better awareness and developing the skills to speak out and speak up when they are encountered (Delgado, Stefancic, and Liendo 20I2).

\section{Methods}

In order to better understand the ways in which the leadership programs are presented to members of the library profession, I carried out a content analysis of public websites and reached out to coordinators and contacts by email. Content analysis has developed over the last quarter-century as a flexible method for examining organizational artifacts, such as these websites, in a non-intrusive way (Duriau, Reger, and Pfarrer 2007). I analyzed the text of the public websites for curricular content, costs, instructor and/or developer information, and objectives. I was looking for common themes concerning what was taught and how it was developed, as well as potential barriers to access through costs, application requirements, or delivery mechanisms. I also wanted to see if there was any overt addressing of equity issues in the profession.

To complement this analysis, I reached out to coordinators and contacts at 17 library leadership development programs via email. The list of programs is provided in Appendix A. I chose these programs from the ALA's listing (ALA 2008). I filtered the list down to those that included academic librarians and seemed to be currently offered. The programs ranged from intensive in-person institutes, to a series of separate in-person meetings, to online-only brief experiences such as webinars or short courses.

I asked the coordinators the following questions via email. After introducing myself and how I was researching leadership offerings in librarianship for how well they met the needs of the profession, I asked:

I. Is your leadership training opportunity still being actively offered?

2. About how many alumni does your opportunity have?

3. How does your organization evaluate your opportunity? What evidence do you gather that shows you meet your objectives?

4. How do you evaluate/reevaluate the objectives of your opportunity, and make changes?

5. How well do you feel your opportunity meets the needs of your particular professional community and of librarianship as a whole? Do you wish you could 
reach particular elements of the community better (e.g., school library workers, early-career professionals, diverse populations), or do you attract the attendees you set out to include?

I did not directly broach a discussion of race/gender and structural bias in the offerings, since I had concerns that approaching the topic too directly would trigger white fragility on the part of study participants. White fragility, as set forth by Robin DiAngelo (20II), "is a state in which even a minimum amount of racial stress becomes intolerable, triggering a range of defensive moves" (54). I had learned in some fumbling informal encounters how quickly our majority-white profession shuts down discourse about race, particularly if there is a feeling of blame around the topic: a perception that leadership programs were not helping or possibly were hindering bias problems, for example. I had hoped to have some email exchanges or phone conversations to follow up on the answers I received and to introduce more charged topics, but this did not work out for reasons discussed below.

\section{Results}

Each program examined had an active website at the start of 2017 and showed evidence that it was recruiting participants or preparing for a new offering. Each website listed some learning objectives or intended outcomes for attendees at each offering. Each one discussed building leadership skills extensively, and most gave specific examples, such as communication, team-building, change management, or strategic planning. Seven mentioned networking/building a professional network as an explicit goal of their offering. Nine explicitly mentioned career advancement as an objective. Only six focused explicitly on libraries in connection with their offerings, and none focused explicitly on the values of librarianship. Many of the websites' descriptions of the intended outcomes of their programs would have fit nearly any profession. This information is summed up in Appendix A.

I received a low response rate to my email query to program coordinators and not much additional information from follow-up interactions in which I sought to expand or build on answers. Only nine of the 17 returned my email, and most replies were terse. Most rely on participant satisfaction and numbers of applicants to measure their success and make any sort of programmatic changes, in line with what was discussed in the literature review above. Only one respondent indicated that they were using a tested instrument (Leadership Self-Efficacy Inventory) to evaluate their success and make needed changes. The nine responses are summarized in Appendix B.

The lack of data from those I queried and the generic nature of the information on the websites reinforces the lack of critical analysis about these endeavors illustrated 
in the literature review. The information that I did glean, however, provided enough for an overview of how critical race theory tenets demonstrate problems with these programs.

\section{Analysis}

Reviewing the data gathered from providers through the lens of critical race theory shows that these programs structurally determine how our profession's leadership are often appointed. The program itself is set up as exclusive and normative-an entry into library management and leadership positions. Based on the application processes presented on websites, participants are selected by already installed leaders in our profession, typically through a nomination process, and often must be employed and/or receive extensive financial support from their employers in order to participate. My conversations with providers suggest that the programs are also held as highly personal and transformative, and therefore a premium is placed on participants' narratives as opposed to objective analysis. The exclusiveness of the program, the need to be nominated by an existing leader, the costs, and the emphasis on the face-to-face element of the program set these programs up to reinforce the dominant culture. This is structural determinism in action, and unless there is a desire on the part of the dominant culture to make changes (i.e., actively recruit and support persons of colour and women to attend), material determinism illustrates that structural changes are unlikely.

We can also see how these programs perpetuate the ordinariness of racism, one of the elements of critical race theory. Race or gender barriers in library leadership are not a stated part of the goals or curriculum of any of these offerings, despite clear evidence of barriers in the profession. If we consider these programs through the lens of whiteness in our profession, these programs seem to normalize librarianship as a white profession by promoting universalism: there is one set way to learn leadership, and that is without considering race and gender-despite the clear barriers seen in the numbers in the profession generally and in its leadership in particular.

It was my initial hope that the email sent to the program coordinators would serve as an icebreaker leading to further discussions about how they were addressing issues of diversity, but the initial response rate was low to begin with and what replies I received were brief. Follow-up emails and calls were generally not returned. Part of the problem is that inclusion in these programs is often promoted as exclusive access to content and a particular experience. While this exclusive nature was not mentioned on websites, nor did it come up in my emails with program coordinators, I know from personal experience that some residential programs begin on the first evening with some sort of ceremony or ritual that describes the experience that we 
are all about to undergo as confidential and that celebrates our elite status in being there. The end of the program also reinforces this message with a commencement or initiation rite that creates a feeling of closed or secret society. This sense of secrecy and exclusion may be part of the reason that objective information and data about these programs are hard to find in the literature, and this value on exclusivity by the program administrators demonstrates the lack of interest convergence as set forth by critical race theory.

Most contacts informed me that program success was evaluated based on surveys or feedback forms gathered from participants at the conclusion of the program, with a few also soliciting responses for a one- or six-month follow-up survey. These evaluations are then used to retool or reaffirm the educational offerings. The literature review suggests that these methods are typical for such programs (Skinner and Krabbenhoeft 20I4; Jacobs 2015). One problem with this form of evaluation, particularly given the sense of joining an exclusive club, is the inclination to evaluate the experience based on personal satisfaction with the event and presenters rather than on a more objective look at content, program goals, and probable effect on a participant's work life. This concern is expressed by Skinner and Krabbenhoeft (2014), Jacobs (2015), and Herold (2015), although more mildly. Again, there is a lack of interest convergence: these programs are doing a good-enough job keeping leaders in power, so there is no incentive to examine them further.

These nine respondents measured their program's success largely by the demand for the offering; if they received more applicants than could be accommodated, the offering was seen as successful. This approach overlooks the problem that, for most of the nine respondents' programs, applicants either must be nominated or collect letters of support/recommendation, usually from employers, to attend. This creates the barrier that attendees must be gainfully employed within a library and in addition must be seen as worthy of support by that employer. There is also a secondary problem that applicants and attendees pay tuition and travel expenses to take part in these programs, as well as take time off work. These barriers reinforce the structural determinism at play: library leadership development in its current state is not able to address barriers to leadership effectively. It also further illustrates the material determinism of library leadership development: the current state of training will only perpetuate the current power structures, because there is no incentive not to.

I found it interesting that every one of the nine respondents indicated that their offering meets the needs of their particular professional community and librarianship as a whole. All nine did so primarily with just a sentence affirming the statement and no further analysis, although one said that their efforts to attract 
persons of colour were not as successful as they would like. This was the only time in my discussions with coordinators that diversity issues were mentioned. This illustrates the norm of whiteness within the library profession (Honma 2005): even though the evidence is clear that persons of colour face barriers to leadership roles, leadership training experience providers do not see those barriers as a concern. This further reinforces the structural barriers laid out by critical race theory and the material determinism reinforcing the status quo.

There are two other factors to note. Several of these programs have external creators in common; four programs were created by one individual and four were created by a leadership consulting business. Librarianship rarely came up in my emails with the program coordinators. This echoes concerns brought up by Skinner and Krabbenhoeft (2OI4) about the amount of power that just a handful of people outside of our profession have over the curricula and design of these experiences and further illustrates the material determinism at play, with a lack of interest in change since the current setup perpetuates those leaders in power.

As discussed above, management is defined as the solving of technical problems, such as drafting policies, documenting employee performance, and dealing with difficult customers in the moment. Leadership is defined as higher-level concepts such as strategic planning, building community, and change management. The strong focus in these programs on building management skills may make attendees happy and fill enrolment, but the lack of attention paid to the core values of the professionfor example, those of access, democracy, diversity, and social responsibility enumerated by the ALA and explored above-means that these programs do not move attendees beyond skills development in technical issues. Beyond these valuebased concerns, there is a very real question as to whether these programs actually meet even their prosaic managerial skills-building objectives, due to the lack of data gathered beyond satisfaction measures. These concerns were not much addressed in my contact with the coordinators but have come to light in the literature, as discussed above (Skinner and Krabbenhoeft 2014; Jacobs 2015).

\section{What Can Be Done?}

Library leadership development can be a beneficial way to consider the future of our libraries and the profession: we want to create dy namic environments that attract and nurture dynamic employees in order to provide visionary services, collections, and resources to our communities. To create these environments and support employees, we need ongoing and proactive leadership development programs that address barriers to leadership (Miller 2017). The clear barriers to leadership in librarianship are gender and race, and of these two, race is the greater barrier. 
The current leadership development opportunities reinforce the existing biased structures within librarianship. They do this through structural determinism: supervisors nominate attendees and provide financial support for what is usually an expensive experience away from home, in which an exclusionary environment is built around the content presented. They do this through material determinism: the content consists of skills-based material that furthers the status quo, management-oriented structure. The curriculum rarely addresses issues of stated and demonstrable importance to librarianship and to its leaders, specifically issues of racial and gender bias. This is due to the ordinariness of racism and the universalism of whiteness within the profession. What could be done differently?

My first recommendation is to talk about the problem. The more voices that are raised, the harder they are to ignore. This article is my first step in engaging the profession in a more visible way in a discussion of these informal concerns that I have been hearing about ever since my first professional leadership development experience. I am no "mover or shaker," but as a mid-career professional, a library manager, and someone who is involved in association work, my voice can speak up for those shut out of the conversation. I encourage us to talk bravely and directly about the problems of racism and sexism in librarianship in order to challenge white fragility, particularly if we are ourselves white. Critical race theory offers us tools, centred on storytelling and narrative, that reinforce the value of speaking out and speaking up on issues of race. The idea is to combat the ordinariness of racism by building awareness of how the whiteness of our profession promotes normativity and universalism. This conversation, and thinking critically about our profession, ought to begin in library school and become a foundational part of librarianship, in order to most effectively create the momentum for change on issues of inclusion.

I further suggest to those who create, curate, direct, contribute to, send personnel to, or personally attend library leadership development programs that the content, activities, and attendance need to better reflect our professional mission and values. Additionally, we need to demand evidence that these programs provide meaningful leadership development through better evaluation of success. We must go beyond management-skills training if we want to move the profession forward on issues of race and gender, and we must have transparency about the efficacy of the program as well as the curricular content. Reducing financial and structural barriers (i.e., employer support, residential programs) to participation is a doable first step to reducing the structural determinism that critical race theory warns us about. Directly, honestly, and openly talking about issues of race and gender in librarianship as part of these programs may be challenging, but it is required in order to create leaders who are in tune with our professional values. Normalizing these 
conversations and encouraging participants to carry these conversations back to their home libraries could go a long way to correcting the universalism of whiteness and ordinariness of racism within our profession and help us better reflect our communities.

I also want to see some alternatives to the transformational leadership model that is pervasive throughout library leadership development programs, as our values are ill-served by this approach. I am using this brief study as groundwork and justification to begin work on an action-research project to develop a model curriculum for library leadership development. I plan to use an adaptive leadership model, described by Ronald Heifetz (1993) as "developing the organizational and cultural capacity to meet problems successfully according to our values and purposes" (3). Offering it at a minimal cost in a distributed manner, I plan to centre the curriculum in our professional values and use participants' current work environment or other lived experiences as the "classroom." My goal is to make this curriculum open, complete with assessment tools that can be used to measure the efficacy of the work. I hope to begin testing this model in late 2019 and publish a dissertation based on this work shortly thereafter.

\section{Conclusion}

Librarianship, with its social justice mission and embodied values of diversity, "is especially well-suited to model a more equitable profession" (Morales, Knowles, and Bourg 20I4, 44I). In order for this to happen, a logical place to start is with the leadership of the profession, and leadership development training could be an excellent venue for working for change. The need for libra rianship to alter how it develops leaders, through a focus on better access for participants and on core values rather than skills building, is clear from my brief study, as is the need to develop more librarians of colour for leadership roles. Perhaps the time is right for this change, with the increased awareness that the critical librarianship movement has brought to the profession. The systemic biases at play, however, certainly stack the deck against us, and for us to see any difference will require conscious effort and desire to implement positive movement toward social justice from the upper levels of librarianship. Critical race theory gives us tools to better describe and understand the problems so that we can begin to address them meaningfully, chiefly through a restructuring of both the mechanics and the curriculum of leadership development training.

ABOUT THE AUTHOR

Samantha Hines is Associate Dean of Instructional Resources at Peninsula College in Washington State, USA. She is also a doctoral candidate at Union Institute \& University. She writes and speaks on issues of library management and leadership. 


\section{REFERENCES}

American Library Association. 2004. "Core Values of Librarianship." HTTP://www.ALA.org/ADVoCACY/ INTFREEDOM/COREVALUES

2008. "Library Leadership Training Resources." HTtp://WwW.ALA.ORG/OFFICES/HRDR/ ABOUTHRDR/HRDRLIAISONCOMM/OTLD/LEADERSHIPTRAINING

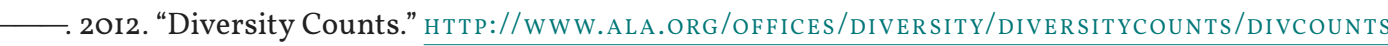

Burns, J. M. 1978. Leadership. New York: HarperCollins.

Canadian Association of Professional Academic Librarians. 2016. "2016 Census of Canadian Academic Librarians User Guide and Results Summary." htTps://CAPALIBRARIANs.org/WP/WP-CONTENT/ UPLOADS/2OI6/I2/CENSUS _ SUMMARY _ AND _ USER_GUIDE_ DECEMBER _ I6 _ 2OI6.PDF

Davis-Kendrick, K. D. 2009. "The African-American Male Librarian: Motivational Factors in Choosing a Career in Library and Information Science." Behavioral \& Social Science Librarian 28: 23-52. H T P S:// DOI.ORG/IO.IO80/OI639260902862066

Delgado, R., J. Stefancic, and E. Liendo. 2012. Critical Race Theory: An Introduction, 2nd ed. New York: New York University Press.

DiAngelo, R. 20II. “White Fragility.” International Journal of Critical Pedagogy 3 (3): 54-70.

Diaz-Saenz, H. R. 20II. “Transformational Leadership." In SAGE Handbook of Leadership, edited by A. Bryman, D. Collinson, K. Grint, B. Jackson, and M. Uhl-Bien, 299-310. Thousand Oaks, CA: Sage.

Douglas, V. A., and J. Gadsby. 2017. "Gendered Labor and Library Instruction Coordinators: The Undervaluing of Feminized Work." In At the Helm: Leading Transformation: The Proceedings of the Association of College and Research Libraries 2017 Conference, March 22-25, 20I7, 266-74. Chicago: Association of College and Research Libraries.

Duriau, V. J., R. K. Reger, and M. D. Pfarrer. 2007. "A Content Analysis of the Content Analysis Literature in Organizational Studies: Research Themes, Data Sources, and Methodological Refinements." Organizational Research Methods IO: 5-34.

Espinal, I. R. 200I. "A New Vocabulary for Inclusive Librarianship: Applying Whiteness Theory to Our Profession." In The Power of Language / El Poder de la Palabra: Selected Papers from the Second REFORMA National Conference, edited by L. Castillo-Speed, I3I-49. Englewood, CO: Libraries Unlimited.

Fletcher, J. K. 1995. "Radically Transforming Work for the 2Ist Century: A Feminist Reconstruction of 'Real' Work." Academy of Management Journal, I995 Meeting Supp: 448-52. H T T P://D D. ORG/I 0.5465/ АмвРP.I995.I7536733

Gibson, A., S. Hughes-Hassell, and M. Threats. 2018. "Critical Race Theory in the LIS Curriculum." In Re-envisioning the MLS: Perspectives on the Future of Library and Information Science Education: Advances in Librarianship $4 B$, edited by Johnna Percell, Lindsay C. Sarin, Paul T. Jaeger, and John Carlo Bertot, 49-70. Bingley, UK: Emerald.

Heifetz, R. A. 1994. Leadership without Easy Answers. Cambridge, MA: Harvard University Press.

Herold, I. M., ed. 2015. Creating Leaders: An Examination of Academic and Research Library Leadership Institutes. Chicago: Association of College and Research Libraries.

Honma, T. 2005. “Trippin' over the Color Line: The Invisibility of Race in Library and Information Science." Interactions: The UCLA Journal of Education and Information Studies I (2): I-26.

International Federation of Library Associations. 20I8. "More about IFLA." htTps://WwW.IFLA.org/ ABOUT/MORE

Jacobs, D. 2015. Cultivating Global Library Leadership: A Review of Leadership Training Programs for Librarians Worldwide. San Francisco: Arabella Advisors.

Lenzini, R. T. 2002. "The Graying of the Library Profession: A Survey of Our Professional Associations and Their Responses." Searcher Io (7): 88-97. 
Leong, J. H. 20I3. "Ethnic Diversity at the University of Toronto Libraries." In Proceedings of the 2013 World Library and Information Congress, 15-23 August. Singapore: International Federation of Library Associations. HTTP://LIBRARY.IFLA.ORG/67/I/IOI-LEONG-EN.PDF

McCleskey, J. A. 20I4. "Situational, Transformational and Transactional Leadership and Leadership Development." Journal of Business Studies Quarterly 5 (4): II7-30.

Miller, R. T. 2017. “A Better Ladder: Fostering the Leaders Libraries Need.” Library Journal 8, March 15.

Morales, M., E. C. Knowles, and C. Bourg. 20I4. "Diversity, Social Justice, and the Future of Libraries." Portal: Libraries and the Academy I4 (3): 439-5I.

Neigel, C. 2015. “LIS Leadership and Leadership Education: A Matter of Gender." Journal of Library Administration 55: 52I-34. HTTPS://DOI.ORG/IO.IO80/OI930826.20I5.1076307

Nixon, J. M. 2008. "Growing Your Own Leaders: Succession Planning in Libraries." Journal of Business and Finance Librarianship I3 (3): 249-60.

Olin, J., and M. Millet. 2015. "Gendered Expectations for Leadership in Libraries." In the Library with the Lead Pipe, November 4. Http://WWW.inthelibrarywiththeleadpipe.org/2 OI5/Libleadgender/

Olivias, A. P. 20I7. “'Should I Stay or Should I Go?' The Motivation of Underrepresented Minority Librarians to Lead." In At the Helm: Leading Transformation: The Proceedings of the Association of College and Research Libraries 2017 Conference, March 22-25, 20I7, 613-26. Chicago: Association of College and Research Libraries.

Pfaff, L. A., K. J. Boatwright, A. L. Potthoff, C. Finan, L. A. Ulrey, and D. M. Huber. 20I3. "Perceptions of Women and Men Leaders Following 360-Degree Feedback Evaluations." Performance Improvement Quarterly 26(I): 35-56. HTTPS://DOI.ORG/IO.IOO2/PIQ.2II34

Skinner, K., and N. Krabbenhoeft. 20I4. Training the 2Ist Century Library Leader: A Review of Library Leadership Training, 1998-2013. Atlanta: Educopia Institute.

Sloniowski, L. 20I6. "Affective Labor, Resistance, and the Academic Librarian." Library Trends 64 (4): $645-66$.

Statistics Canada. 20II. "Table 2: Visible minority population and top three visible minority groups, selected census metropolitan areas, Canada." HTTPS://WWWI2.STATCAN.GC.CA/NHS-ENM/2OII/AS$\mathrm{SA} / 99-O I O-X / 2 O I I O O I / T B L / T B L 2-E N G . C F M$

United States Census Bureau. 20I7. “QuickFacts: Population estimates, July I." нтt ps://wWw.CEnsus. GOV/QUICKFACTS/FACT/TABLE/US/PSTO452I7 
Appendix A: Library Leadership Institutes, Web Content Analysis

\begin{tabular}{|c|c|c|c|c|c|}
\hline $\begin{array}{l}\text { Program } \\
\text { Name }\end{array}$ & Location & Cost & $\begin{array}{l}\text { Oucomes/ } \\
\text { Content Themes }\end{array}$ & Modality & $\begin{array}{l}\text { Created } \\
\text { Internally/ } \\
\text { Externally }\end{array}$ \\
\hline $\begin{array}{l}\text { ALA Emerging } \\
\text { Leaders }\end{array}$ & varies & $\begin{array}{l}\text { not } \\
\text { stated }\end{array}$ & $\begin{array}{l}\text { career advancement, } \\
\text { networking, } \\
\text { skills development }\end{array}$ & $\begin{array}{l}\text { in-person, } \\
\text { two I-day } \\
\text { sessions, plus } \\
6 \text { months } \\
\text { online }\end{array}$ & externally \\
\hline $\begin{array}{l}\text { ARL Leadership } \\
\text { Fellows }\end{array}$ & not stated & $\begin{array}{l}\text { \$IO 500- } \\
\text { \$I } 2 \text { OOO } \\
\text { USD }\end{array}$ & $\begin{array}{l}\text { skills development, } \\
\text { libraries are } \\
\text { specifically addressed }\end{array}$ & $\begin{array}{l}\text { in-person, } \\
\text { 3-week-long } \\
\text { sessions over } \\
\text { I8 months }\end{array}$ & internally \\
\hline Aurora Institute & $\begin{array}{l}\text { New South } \\
\text { Wales, } \\
\text { Australia }\end{array}$ & $\begin{array}{l}\$ 5400 \\
\text { AUD }\end{array}$ & $\begin{array}{l}\text { career advancement, } \\
\text { networking, } \\
\text { skills development }\end{array}$ & $\begin{array}{l}\text { in-person, } \\
6 \text { days }\end{array}$ & externally \\
\hline $\begin{array}{l}\text { Harvard } \\
\text { Leadership } \\
\text { Institute for } \\
\text { Academic } \\
\text { Librarians }\end{array}$ & $\begin{array}{l}\text { Massachu- } \\
\text { setts, USA }\end{array}$ & $\begin{array}{l}\$ 3600- \\
\$ 3800 \\
\text { USD }\end{array}$ & $\begin{array}{l}\text { skills development, } \\
\text { libraries are } \\
\text { specifically addressed }\end{array}$ & $\begin{array}{l}\text { in-person, } \\
6 \text { days }\end{array}$ & mixed \\
\hline $\begin{array}{l}\text { Michigan Library } \\
\text { Association } \\
\text { Leadership } \\
\text { Academy }\end{array}$ & $\begin{array}{l}\text { Michigan, } \\
\text { USA }\end{array}$ & $\begin{array}{l}\text { \$I } 295^{-} \\
\$ 2395 \\
\text { USD }\end{array}$ & $\begin{array}{l}\text { career advancement, } \\
\text { skills devleopment, } \\
\text { libraries are } \\
\text { specifically addressed }\end{array}$ & $\begin{array}{l}\text { in-person, } \\
5 \text { non- } \\
\text { consecutive } \\
\text { days }\end{array}$ & unclear \\
\hline $\begin{array}{l}\text { Mountain Plains } \\
\text { Library } \\
\text { Association }\end{array}$ & $\begin{array}{l}\text { Colorado, } \\
\text { USA }\end{array}$ & $\begin{array}{l}\text { \$600- } \\
\$ 800 \text { USD }\end{array}$ & $\begin{array}{l}\text { career advancement, } \\
\text { networking, } \\
\text { skills development }\end{array}$ & $\begin{array}{l}\text { in-person, } \\
6 \text { days }\end{array}$ & externally \\
\hline $\begin{array}{l}\text { New England } \\
\text { Library } \\
\text { Leadership } \\
\text { Symposium }\end{array}$ & $\begin{array}{l}\text { Massachu- } \\
\text { setts, USA }\end{array}$ & $\begin{array}{l}\text { not } \\
\text { stated }\end{array}$ & $\begin{array}{l}\text { career advancement, } \\
\text { skills development, } \\
\text { libraries are } \\
\text { specifically addressed }\end{array}$ & $\begin{array}{l}\text { in-person, } \\
5 \text { days }\end{array}$ & externally \\
\hline $\begin{array}{l}\text { New York } \\
\text { Leadership } \\
\text { Academy }\end{array}$ & $\begin{array}{l}\text { New York, } \\
\text { USA }\end{array}$ & $\$ 800$ USD & $\begin{array}{l}\text { career advancement, } \\
\text { skills development }\end{array}$ & $\begin{array}{l}\text { in-person, } \\
\text { 3-year } \\
\text { (meeting } 3 \\
\text { times a year) }\end{array}$ & $\begin{array}{l}\text { internally, } \\
\text { modeled on } \\
\text { other } \\
\text { programs }\end{array}$ \\
\hline $\begin{array}{l}\text { North Carolina } \\
\text { Library } \\
\text { Association }\end{array}$ & $\begin{array}{l}\text { North } \\
\text { Carolina, } \\
\text { USA }\end{array}$ & $\$ 400$ USD & $\begin{array}{l}\text { career advancement, } \\
\text { networking, } \\
\text { skills development }\end{array}$ & $\begin{array}{l}\text { in-person, } \\
4 \text { days }\end{array}$ & unclear \\
\hline
\end{tabular}




\begin{tabular}{|c|c|c|c|c|c|}
\hline $\begin{array}{l}\text { Program } \\
\text { Name }\end{array}$ & Location & Cost & $\begin{array}{l}\text { Oucomes/ } \\
\text { Content Themes }\end{array}$ & Modality & $\begin{array}{l}\text { Created } \\
\text { Internally/ } \\
\text { Externally }\end{array}$ \\
\hline $\begin{array}{l}\text { Northern } \\
\text { Exposure to } \\
\text { Leadership }\end{array}$ & $\begin{array}{l}\text { Alberta, } \\
\text { Canada }\end{array}$ & $\begin{array}{l}\$ 2950 \\
\mathrm{CAD}\end{array}$ & skills development & $\begin{array}{l}\text { in-person, } \\
7 \text { days }\end{array}$ & externally \\
\hline $\begin{array}{l}\text { Pacific Northwest } \\
\text { Library } \\
\text { Association }\end{array}$ & $\begin{array}{l}\text { Washington, } \\
\text { USA }\end{array}$ & $\begin{array}{l}\text { \$I OOO } \\
\text { USD }\end{array}$ & $\begin{array}{l}\text { skills development, } \\
\text { libraries are } \\
\text { specifically } \\
\text { addressed }\end{array}$ & $\begin{array}{l}\text { in-person, } \\
6 \text { days }\end{array}$ & externally \\
\hline $\begin{array}{l}\text { Pennsylvania } \\
\text { Library } \\
\text { Association } \\
\text { Academy of } \\
\text { Leadership } \\
\text { Studies }\end{array}$ & $\begin{array}{l}\text { Pennsylva- } \\
\text { nia, USA }\end{array}$ & $\begin{array}{l}\text { \$400- } \\
\$ 500 \text { USD }\end{array}$ & $\begin{array}{l}\text { networking, } \\
\text { skills development }\end{array}$ & $\begin{array}{l}\text { in-person, } \\
3.5 \text { days }\end{array}$ & internally \\
\hline $\begin{array}{l}\text { Siena } \\
\text { Leadership } \\
\text { Institute for } \\
\text { Academic Library } \\
\text { Managers }\end{array}$ & $\begin{array}{l}\text { New York, } \\
\text { USA }\end{array}$ & $\begin{array}{l}\text { \$I } 425 \\
\text { USD }\end{array}$ & $\begin{array}{l}\text { career advancement, } \\
\text { skills development }\end{array}$ & $\begin{array}{l}\text { in-person, } \\
6 \text { days }\end{array}$ & internally \\
\hline $\begin{array}{l}\text { Sunshine State } \\
\text { Library } \\
\text { Leadership } \\
\text { Institute }\end{array}$ & Florida, USA & $\$ 300$ USD & $\begin{array}{l}\text { networking, } \\
\text { skills development }\end{array}$ & $\begin{array}{l}\text { in-person, } \\
\text { Io non- } \\
\text { consecutive } \\
\text { days }\end{array}$ & internally \\
\hline TALL Texans & Texas, USA & $\$ 850$ USD & $\begin{array}{l}\text { career advancement, } \\
\text { skills development }\end{array}$ & $\begin{array}{l}\text { in-person, } \\
5 \text { days }\end{array}$ & externally \\
\hline $\begin{array}{l}\text { Wyoming Library } \\
\text { Leadership } \\
\text { Institute }\end{array}$ & $\begin{array}{l}\text { Wyoming, } \\
\text { USA }\end{array}$ & $\begin{array}{l}\text { not } \\
\text { stated }\end{array}$ & $\begin{array}{l}\text { network, } \\
\text { skills development, } \\
\text { libraries are } \\
\text { specifically } \\
\text { addressed }\end{array}$ & $\begin{array}{l}\text { in-person, } \\
3 \text { days }\end{array}$ & externally \\
\hline
\end{tabular}




\section{Appendix B: Information Provided by Program Coordinators}

\begin{tabular}{|c|c|c|c|c|}
\hline $\begin{array}{l}\text { Program } \\
\text { Name }\end{array}$ & $\begin{array}{l}\text { Number } \\
\text { of } \\
\text { Alumni }\end{array}$ & $\begin{array}{l}\text { Evaluation of } \\
\text { Opportunity }\end{array}$ & $\begin{array}{l}\text { Evaluation of } \\
\text { Objectives }\end{array}$ & $\begin{array}{l}\text { Satisfaction } \\
\text { with Experience } \\
\text { Evaluation }\end{array}$ \\
\hline $\begin{array}{l}\text { Harvard } \\
\text { Leadership } \\
\text { Institute for } \\
\text { Academic } \\
\text { Librarians }\end{array}$ & unknown & satisfaction survey & $\begin{array}{l}\text { satisfaction survey, } \\
\text { team meetings }\end{array}$ & $\begin{array}{l}\text { appliant demand/quality, } \\
\text { test of time }\end{array}$ \\
\hline $\begin{array}{l}\text { Mountain } \\
\text { Plains Library } \\
\text { Association }\end{array}$ & 300 & satisfaction survey & satisfaction survey & impressionistic satisfaction \\
\hline $\begin{array}{l}\text { New York } \\
\text { Leadership } \\
\text { Academy }\end{array}$ & $50+$ & satisfaction survey & satisfaction survey & impressionistic satisfaction \\
\hline $\begin{array}{l}\text { North Caroli- } \\
\text { na Library } \\
\text { Association }\end{array}$ & I 25 & $\begin{array}{l}\text { satisfaction survey } \\
\text { project comple- } \\
\text { tion }\end{array}$ & $\begin{array}{l}\text { satisfaction survey, } \\
\text { mentor feedback }\end{array}$ & $\begin{array}{l}\text { applicant demand/quality, } \\
\text { acceptance rate, } \\
\text { openly inclusive and } \\
\text { representative of the state }\end{array}$ \\
\hline $\begin{array}{l}\text { Northern } \\
\text { Exposure to } \\
\text { Leadership }\end{array}$ & $400+$ & $\begin{array}{l}\text { Leadership } \\
\text { Self-Efficacy } \\
\text { Inventory pre- } \\
\text { and post-tests }\end{array}$ & $\begin{array}{l}\text { applying results of } \\
\text { Leadership Self- } \\
\text { Efficacy Inventory }\end{array}$ & nomination rate \\
\hline $\begin{array}{l}\text { Pacific } \\
\text { Northwest } \\
\text { Library } \\
\text { Association }\end{array}$ & 200 & $\begin{array}{l}\text { satisfaction survey } \\
\text { I- month } \\
\text { follow-up }\end{array}$ & $\begin{array}{l}\text { satisfaction survey, } \\
\text { follow-up survey, } \\
\text { occasional alumni } \\
\text { survey }\end{array}$ & $\begin{array}{l}\text { impressionistic satisfaction, } \\
\text { would like to recruit more } \\
\text { paraprofessionals, school } \\
\text { professionals, and tribal } \\
\text { librarians }\end{array}$ \\
\hline $\begin{array}{l}\text { Siena } \\
\text { Leadership } \\
\text { Institute for } \\
\text { Academic } \\
\text { Library } \\
\text { Managers }\end{array}$ & $50+$ & satisfaction survey & $\begin{array}{l}\text { satisfaction survey, } \\
\text { team meetings }\end{array}$ & $\begin{array}{l}\text { applicant demand/quality, } \\
\text { impressionistic satisfaction }\end{array}$ \\
\hline $\begin{array}{l}\text { Sunshine } \\
\text { State Library } \\
\text { Leadership } \\
\text { Institute }\end{array}$ & unknown & $\begin{array}{l}\text { project } \\
\text { completion }\end{array}$ & review of projects & applicant demand/quality \\
\hline
\end{tabular}

